\title{
Entryism in Theory, in Practice, and in Crisis: The Trotskyist Experience in New Brunswick, 1969-1973
}

By Patrick Webber

Since the emergence of a distinct Trotskyist faction within the Communist movement by the mid-1930s, the policy of entryism has been a favourite tactic among Trotskyists, particularly in the West. Entryism would be a major factor in the creation of the New Brunswick Waffle in 1970, the provincial wing of the Waffle movement that had emerged in the New Democratic Party (NDP) the previous year. ${ }^{1}$ Conflicting interpretations over the implementation of entryist theory, however, would also help split and destroy the NB Waffle by the end of 1971 and inflict lethal damage on the nascent Trotskyist movement in New Brunswick. The ultimate impact of the crisis in entryism provoked by the Trotskyist experience in New Brunswick in 1970-71 was to raise major doubts about the theory and practice of entryism among Canadian Trotskyists, culminating in the fracturing of the League for Socialist Action (LSA), Canada's pre-eminent Trotskyist organization. The events that surrounded the NB Waffle therefore proved to be a turning point in the history of Trotskyist strategy in Canada.

The strategy of entryism was first known as the "French Turn," as it was first in France where Trotskyists debated and engaged in entryism. In June 1934, Trotsky himself declared that his followers in that country should seek to enter the French Socialist Party, a shift in policy that was provoked by the formation of a United Front. Trotsky believed that the Trotskyist movement had to be within the United Front in order to not be excluded from the shaping of a potential revolution. Trotsky thought that an independent Trotskyist organization would be isolated from the larger leftist movement and even destroyed. By entering larger leftist parties, Trotskyists could exert influence among the working classes with less risk of being isolated. ${ }^{2}$

Entryism was thus born as a pragmatic response to the local weakness of sectarian Trotskyist appeals by entering larger political organizations that offer both protection from isolation and access to the larger working class. ${ }^{3}$ Almost as soon as Trotsky proposed entryism to his French followers, however, the idea sparked debate. ${ }^{4}$ While there are conflicting interpretations of what exactly entryism is and what it is supposed to achieve, there are some basic tenets of the strategy that offer a good broad definition of entryism. According to John Tomlinson, entryism (be it Trotskyist or not) has three basic objectives for its participants: 
1. To identify support for its own cause within the host group, or stimulate it;

2. To provoke and/or exploit division within that group to its own political ends and in order to achieve a degree of executive power;

3. To exert influence on the nature and direction of policy within the infiltrated group. ${ }^{5}$

For the purposes of this article, the above definition of entryism will be employed. ${ }^{6}$ It can be argued that any definition of entryism within the far left at least embodies all of the above aims. Of course, these agreed upon stated aims of entryism did not always coincide with the practised aims of entryism, and therein lies one of the major schisms that this article will reveal. The story of the Trotskyists in New Brunswick in the early 1970s is fundamentally a story of such a schism.

Along with France, entyrism also had practitioners in Chile and the United States during the 1930s, ${ }^{7}$ though Canadian Trotskyists were not far behind. Indeed, the history of the Canadian Trotskyist movement has largely been dominated by debates around the question of entryism. Canadian Trotskyists bitterly debated whether entryism ought to be practiced in the newly formed and socialist Co-Operative Commonwealth Federation (CCF). As Canada's primary socialist party, the CCF was the primary target of any Trotskyists hoping to enact entryist tactics. A narrow majority of Canadian Trotskyists originally endorsed entryism and many on the minority side waited a year before entering the CCF, while several original Trotskyist leaders left the movement. Trotskyist entryism into the CCF began in 1936, though the attempt was short-lived. ${ }^{8}$ Throughout the Second World War, Canadian Trotskyists preferred both the open and independent existence of a sectarian Trotskyist group yet recognized "the varying opportunities that present themselves in different sections of the CCF." By the early 1950s, however, Canadian Trotskyists had almost en masse been converted to the belief that full-scale entryism into the CCF was the correct path to follow, arguing that any future worker upsurge would ultimately gravitate towards the party and that Trotskyists ought to be in the fray. ${ }^{10}$

A policy of entryism was extended by Canadian Trotskyists into the NDP, which grew out of the CCF and the Canadian Labour Congress in 1961. The new party was actually seen as embodying greater potential for Trotskyist influence because the NDP, unlike the CCF, would be affiliated with the labour movement. ${ }^{11}$ Canada's largest Trotskyist organisation, the League for Socialist Action (LSA), adopted the rallying cry of "win the New Party to a socialist policy" when the NDP was being formed. ${ }^{12}$

Throughout the 1960s, Trotskyists associated with the LSA and its youth wing, the Young Socialists (YS), made numerous attempts to enter and influence the NDP. Among these attempts was a short-lived effort in 1963 in New Brunswick, where two LSA members spent the summer contacting NDP mem- 
bers, particularly youth, throughout the province. ${ }^{13}$ This first attempt at entryism in New Brunswick accomplished little. However, things would be different when Trotskyists emerged as a force in the province again, this time in the changed political climate of 1969. Marxist political views were increasing in popularity among Western university students during the late 1960s, in part because Moscow no longer dominated the world Communist movement, which enhanced its appeal. ${ }^{14}$ Trotskyism in particular gained many campus-oriented converts throughout the West during this period, in large part because it was not associated with the crimes of the Stalinist era. ${ }^{15}$ As the burgeoning strength of Trotskyism during the late 1960s was almost exclusively among students, Trotskyists saw an opportunity in forging links with the other currents of political radicalism that were swirling around campuses at the time, namely the New Left.

There already was a small but very active New Left community in Fredericton, centred around the University of New Brunswick, by the end of the 1960s. Its most prominent expression by 1969 was a group named Canadian Struggle for a Democratic Society (CSDS), modeled off of the American Students for a Democratic Society (SDS). CSDS was formed in late 1967 by a collection of radical students and Norman Strax, a physics professor whose name would achieve nationwide recognition the following year during "the Strax Affair."16 By 1969, CSDS was the only significant New Left organisation at UNB, an eclectic mix of self-identified anarchists, left-libertarians and socialists united around a basic anticapitalist and countercultural ethos. According to one CSDS member, Dan Weston, the group did not have a defined ideology or program. Rather, it sought to provoke debate about the nature of a modern industrial capitalist society and conduct actions that "could force the state to have to live up to its democratic façade."’

Trotskyism made its debut at UNB in the summer of 1969 when a $32-$ year old member of the physics department, Eustace Mendis, arrived in Fredericton. Mendis had previous involvement with the Trotskyist Young Socialist Alliance in Madison, Wisconsin and with the significant Trotskyist movement in his native Ceylon (now Sri Lanka)..$^{18}$ Mendis began to involve himself in CSDS in the fall of 1969 and soon attracted a base of support within the group for Trotskyist ideas. The impact of this growing support for Trotskyism (or at least a more doctrinaire form of socialism) was to initiate an open split within CSDS by mid-November. ${ }^{19}$ The split was the product of the incompatibility of the anarchist and left-libertarian tendency and consensus form of decision-making of the group centred on Strax and the ideological socialism and democratic centralism of the Mendis group. By December the Mendis group had decided to form a separate and overtly socialist organization, which became known as the New Brunswick Socialists (NBS). ${ }^{20}$ The NBS was officially formed on 10 December 1969, bringing together local socialists of various persuasions with the stated objective of building "a strong Socialist movement on the campus and simultaneously to direct 
the campus activists into the larger left-wing community." ${ }^{21}$ The NBS was a small group, beginning with no more than fifteen people involved to varying degrees.22

While more politically consistent than CSDS, the NBS was not a politically homogenous grouping. By its own admission, it was initially "a centrist socialist grouping, containing within it left-liberal, social-democratic, ultraleft and even Stalinist tendencies in addition to a solid core moving towards Trotskyism." Soon after its founding, however, Trotskyists believed they had consolidated themselves as the leadership of the NBS. ${ }^{23}$ The leadership of the NBS, which included Mendis and Terry Hamilton-Smith, a student from Ontario and recent convert to Trotskyism, sought to recast the NBS along more Trotskyist lines. In January 1970, Mendis contacted the LSA headquarters in Toronto expressing interest in turning the group into a Fredericton local of the YS. ${ }^{24}$ The Fredericton Young Socialists (FYS) was established in April 1970 and functioned alongside the NBS (each group had almost identical membership lists) until July. ${ }^{25}$

The FYS-NBS members (both Trotskyists and independent socialists) were united in their interest in becoming involved in the NDP in Fredericton, and decided to approach the local party in late April 1970. To become intertwined in the NDP was of course a primary aim of LSA/YS members during the period. However, the NDP riding association in York-Sunbury (the federal riding that encompassed Fredericton and surrounding communities) was largely moribund in early 1970. It had only four or five members and had not met in two years. ${ }^{26}$ The most prominent member of the NDP in Fredericton was Pat Callaghan, a Scottish-born window cleaning business owner in his early 40s and a committed, uncompromising socialist. The FYS-NBS approached him in the spring of $1970 .^{27}$

Callaghan was ecstatic about the young leftists who approached him, and surprised many of them when they realized how left-wing his own politics were. ${ }^{28}$ One FYS member was pleased to report back to an LSA comrade in Toronto that he "seems fairly good: he supports [Ontario Waffle co-leader] Watkins and feels there are too many right-wing elements in the NDP now." ${ }^{29}$ Soon after this encounter, the York-Sunbury NDP held a riding association meeting at which Callaghan was elected president and Mendis was elected secretary. The influx of FYS-NBS members into the York-Sunbury NDP was great enough that they had, along with Callaghan, an almost total monopoly over the local party. The prospect of forming a Waffle group in New Brunswick was immediately discussed. ${ }^{30}$ Committed Trotskyists on the riding association saw the creation of a local Waffle organization as offering a perfect opportunity for enacting an entryist strategy, and hoped to influence the group with Trotskyist ideas. ${ }^{31}$ The FYS were not unique in this line of thought, as the rise of the Waffle was regarded by the LSA across Canada as offering a golden opportunity for increased Trotskyist influence within the NDP. ${ }^{32}$ Callaghan and others meanwhile were attracted to the socialist policies espoused in the Waffle Manifesto. ${ }^{33}$ With everyone in York-Sunbury behind the idea, the New Brunswick Waffle was unofficially formed in the late spring of 1970. 
For the remainder of its existence, the NB Waffle was a fusion of two tendencies. One was a Trotskyist tendency, dominated by the FYS, while the other was a non-Trotskyist tendency, influenced by Callaghan and consisting of crosssection of democratic socialists and New Leftists. Trotskyist activity in New Brunswick, however, was not confined to involvement in the NB Waffle. Eustace Mendis left Fredericton in July 1970, after which Terry Hamilton-Smith became the leader of the FYS. ${ }^{34}$ By this time, the local became a fixture in Fredericton's anti-war and feminist movements and recruited several students at the city's sole high school. The FYS also made contact with other Trotskyist sympathizers elsewhere in New Brunswick, including a collection of people in the Black's Harbour/Beaver Harbour area of Charlotte County who were interested in the NBS in May $1970 .^{35}$

The activities of the FYS within the NDP attracted the attention of Ross Dowson, the LSA's national secretary. Dowson was a seasoned veteran within the Canadian Trotskyist movement, having risen to prominence during the Second World War. Originally skeptical about entryism, he fully supported the strategy by the time of the formation of the NDP. ${ }^{36}$ He also was a student of the history of the far left in Canada, and believed that the Canadian Trotskyist movement suffered from a lack of ideological maturity during its early days. He recalled that:

the growth of the [Canadian Trotskyist movement] was based not on experienced revolutionists who had come through years of struggle in the Stalinized [Communist Party] but on new recruits to Marxism. The difference in ideological maturity between the leading two or three comrades and the membership was vast and great responsibilities were thrown on the leadership. ${ }^{37}$

It seems that Dowson believed that this ideological immaturity was becoming evident among the Trotskyists in New Brunswick, and he sought to provide some leadership for the new recruits to the movement.

Dowson wrote a letter to the local in June 1970 (the only communication between himself and the FYS between the local's formation and the summer of 1971) advising the local to not intervene in the NDP for fear that such intervention would result in their expulsion for the party. The FYS was not particularly sympathetic to Dowson's worries and ignored his advice, believing that they were secure against any expulsion attempts because of the strong position they occupied in the New Brunswick NDP. ${ }^{38}$ York-Sunbury was indeed becoming a major base of NDP activity in New Brunswick throughout 1970. By September, NDP membership in York-Sunbury had risen to 25, the second largest membership base in the province. ${ }^{39}$ These increases were the result of the activities of the NB Waffle, who were acquiring a reputation as party builders. ${ }^{40}$ In September 1970, the NB NDP was preparing for its first major electoral effort since its founding in 1962 as an election was called for 26 October. The NB Waffle officially launched 
itself at the party's convention that same month. None of the NB NDP's 31 candidates (out of 58 seats) won their seats, yet the party did establish itself as a minor political force in anglophone New Brunswick. The NB Waffle, with its significant Trotskyist influence, assisted in this phenomenon. ${ }^{41}$

The Trotskyist influence in the NB Waffle was proportionally impressive by the time of the group's official founding. In late September 1970 the NB Waffle had about 40 members, 22 of whom were in the YS. The YS enjoyed a spate of geographic expansion and enhanced political influence in late 1970 and early 1971. A YS local was established in Black's Harbour/Beaver Harbour in November 1970 and had seven members by February 1971. The YS local formed the nucleus of NB Waffle support in Carleton-Charlotte, the federal riding in which the local resided, and by the end of 1970 the group had control of the NDP riding association there. ${ }^{42}$ Late 1970 and early 1971 was a period in which the geographic and numerical expansion of the Waffle and Trotskyist movement in New Brunswick were interconnected. By February 1971, NDP membership in YorkSunbury had reached 77, and NDP membership in Carleton-Charlotte rose to 46, making these Waffle-dominated ridings the strongest New Brunswick NDP bases. ${ }^{43}$ Waffle domination in these ridings grew out of YS locals. YS locals were set up in early 1971 in Saint John and Sackville as well, though the Sackville local was short-lived. ${ }^{44}$ The Saint John YS grew out of a group of identified Waffle supporters in the city, and by April the NB Waffle gained control of the Saint John NDP riding association. ${ }^{45}$

It is important to note that by early 1971 the Trotskyist movement was a full-fledged part of the radical left-wing community in Fredericton and Charlotte County, and to a lesser extent elsewhere in anglophone New Brunswick. February 1971 was a particularly busy month for the FYS. The local prompted larger NB Waffle participation in a pro-choice rally and a protest against the U.S. invasion of Laos in Fredericton, In addition, two YS members ran in the UNB student elections, including a Presidential candidate, Ron Gaudet, who secured twenty-three percent of the vote. ${ }^{46}$

The unity between the Trotskyist and non-Trotskyist wing of the NB Waffle, however, was not universal, as demonstrated at an NB NDP policy meeting outside of Saint John in March 1971. YS members in the NB Waffle were in Halifax on the weekend of the policy meeting, attending the Atlantic Regional Socialist Conference (the Halifax YS was the other major participant in this conference). ${ }^{47}$ Non-Trotskyist Wafflers, however, did attend the policy meeting, and presented a resolution calling for the removal of marijuana possession from the Narcotics Control Act and the government-administered sale of the drug. The resolution passed by a vote of twenty to eight, sparking the first major dispute between the NB Waffle and the rest of the NB NDP. Wafflers argued that all resolutions that are passed automatically became party policy while non-Wafflers stated that only resolutions passed at conventions became party policy. The dispute 
became public and was eventually settled, or at least put on hold, by the end of March, ${ }^{48}$ but the experience convinced the Trotskyist wing of the NB Waffle to strengthen their control over the group. That an open split in the NB NDP was initiated by non-Trotskyists over what was regarded as a trivial issue was seen as jeopardizing the entryist project of New Brunswick Trotskyists, necessitating greater Trotskyist direction of the group. By the spring of 1971 the Trotskyist wing of the NB Waffle was preparing the group for an eventual victory over the NB NDP at the party's convention in September. ${ }^{49}$

Throughout the summer of 1971, New Brunswick's Trotskyists were busy. They convinced the NB Waffle to make a foray into municipal politics. The NDP ran nine candidates in the June civic elections, six of whom were YS members. FYS member Ron Gaudet was the most high-profile candidate, running for mayor of Fredericton and securing over six percent of the vote. ${ }^{50}$ YS contacts were made in Moncton in July, raising hopes that the NB Waffle could secure control over the local NDP riding association..$^{51}$ The FYS was also discussing NB NDP convention strategy. YS members who had not yet joined the NDP were encouraged to do so to assist the NB Waffle cause. ${ }^{52}$ The FYS decided that a slate of Wafflers would be presented for leadership positions within the NB NDP, though YS members would not take part. This tactic was agreed on to avoid a redbaiting campaign directed against YS members. Instead, they would exert influence from behind the scenes, including the inclusion of a labour policy in the NB Waffle platform designed along Trotskyist lines. Speculation among YS members on what they would do following a supposed NB Waffle victory was fluid,,$^{53}$ perhaps reflecting the fact that many of the Trotskyist members of the group were recent converts to Trotskyism and not hardened ideological theoreticians. The fact that the nascent Trotskyist movement in New Brunswick consisted primarily of fresh recruits would prove to sour relations between themselves and the more dogmatic LSA leadership.

LSA national secretary Ross Dowson, upon reading of the New Brunswick Trotskyists' urging of the NDP to contest June's municipal elections, contacted the FYS again in July to demand a change of strategy. As he had previously made clear, Dowson was concerned that such open involvement of YS members within the NDP would risk their expulsion from the party. His ultimate fear was that the federal NDP leadership would panic at the prospect of a Trotskyist takeover of the NB NDP and engage in a wholesale expulsion of YS members from the party across Canada. Dowson believed that Canada was being swept up in a "wave of radicalization" and that this was being reflected in the NDP. An expulsion of Trotskyists from the party would "constitute a serious rupture in our work to further radicalize the NDP." In the interest of avoiding such a rupture, Dowson instructed the New Brunswick YS members to adopt a more tempered and cautious policy of working within the NDP. Once again, the FYS was not receptive to Dowson's concerns, asserting that he was forcing strategies 
for Trotskyists in Ontario upon Trotskyists in New Brunswick. According to the FYS, the left in New Brunswick was small enough and radical enough to make "formulations which would be anathema in Ontario" acceptable in the province.

Beginning in late August 1971 the NB Waffle started preparing a manifesto and platform to be presented at the NB NDP convention, which was complete by mid-September. The platform featured an eclectic mix of socialist, New Left, anarcho-syndicalist, counter-cultural and revolutionary Marxist positions, all of which reflected the distinctive coalition nature of the NB Waffle in particular and the left in Anglophone New Brunswick in general. It advocated, among other things, the common ownership and nationalisation of almost the entire economy (without compensation), and the abolition of compulsory education. ${ }^{55}$ The Trotskyist wing of the NB Waffle made two contributions to the platform..$^{56}$ The first was a labour resolution that emphasized unions as a major vehicle for working class action. It called for unions to be guided by a socialist party, called for "the formation within unions of a militant, politically-conscious leadership," and insisted that the NDP grant unconditional support to all strikes. ${ }^{57}$ Their second contribution was a resolution on women's rights, calling for equal pay for equal work, an end to sex-based discrimination, free 24-hour childcare centres and abortion on demand..$^{58}$ The Trotskyist contribution to the NB Waffle platform, while limited, was impressive considering that at the beginning of September the YS members in the group were suddenly thrown into deep confusion.

On 1 September 1971, the YS' Central Executive Council (CEC), the Toronto-based body that oversaw pan-Canadian YS activities, decided to suspend "from all rights of membership but not from any of the obligations of membership," the members of the Fredericton YS local. This suspension was to be followed up by an investigation conducted by a YS-established commission. The terms of the suspension dictated that the local would issue no statements in the name of the YS but that they would be obligated to fulfill other membership commitments, including dues payments. The decision was made on the grounds that the FYS had engaged in dishonest practices in their dealings with the LSA and YS leadership and that the local was jeopardizing the entire Canadian Trotskyist movement. Among the most serious charges levied against the FYS was that the local's work within the NB NDP went against LSA policy. ${ }^{59}$

The FYS was thrown into immediate confusion, namely because they did not know whether working within the NDP constituted a right that was to be abandoned or an obligation that ought to be continued. The FYS sought clarification on the matter in a letter sent to the CEC on 22 September, the urgency of the matter exacerbated by the approaching NB NDP convention. No response was received. ${ }^{60}$ Two YS members attended an NB Waffle meeting in Fredericton on 12 September in the hope of intervening in the direction of the group yet had little success. ${ }^{61}$ Uncertain as to how to proceed, the FYS slowly withdrew from 
involvement in the NB Waffle. For the FYS to do so on the eve of the NB NDP convention, where the showdown with non-Wafflers was anticipated, generated a great deal of resentment among non-Trotskyist Waffle members. One frustrated non-Trotskyist Waffler described the FYS action as "coitus interruptus" and YS influence in the group began to decline. ${ }^{62}$

A few YS members were among the 89 delegates who attended the NB NDP convention in Saint John on 25 September 1971. The first day witnessed a surprise victory for the NB Waffle manifesto, which passed by a vote of forty-one to forty, with four abstentions. Several anti-Waffle labour delegates walked out of the convention following the vote, ensuring that the convention lacked quorum and was thus thrown into chaos. Both Waffle and non-Waffle members agreed to postpone the convention until 16 October, to be held in Fredericton. ${ }^{63}$ That evening the Saint John convention effectively came to an end with both sides determined to come out victorious in the struggle for control of the NB NDP that had been launched. ${ }^{64}$

NB Waffle opponents appealed to the federal NDP for assistance, arguing that there were inconsistencies at the Saint John convention that rendered it invalid, while the non-Trotskyist wing of the NB Waffle went about signing up new members in Fredericton in an attempt to overwhelm the 16 October meeting. ${ }^{65}$ The Trotskyist wing of the NB Waffle, however, was not involved in the preparations for the upcoming meeting. Instead, they sought Ross Dowson's input on the developing split within the NB NDP, and Terry Hamilton-Smith telephoned Dowson on 28 September to discuss what was happening. ${ }^{66}$ The FYS believed that the NB Waffle would win over the NB NDP at the 16 October meeting and that that offered a golden opportunity to enhance Trotskyist influence in the party. They also hoped to maximize Trotskyist influence over the NB Waffle's newfound labour support. ${ }^{67}$ Dowson was not convinced by the FYS's assessment of the situation to adopt their stance. Firstly, he considered the NB Waffle manifesto to be unrepresentative of the interests of the Trotskyists movement. ${ }^{68}$ Secondly, he and the rest of the LSA leadership feared that the NB Waffle would precipitate a split within the NB NDP that would ruin the party as a vehicle for Trotskyist entryism. This was because the party lacked a working class or union base in New Brunswick, and this base had to be established before Trotskyists could hope to influence the party membership in any meaningful way. ${ }^{69}$

Dowson attempted to further clarify matters for the FYS in a letter he sent to the local on 3 October in which he stated that he expected them to follow the "declared and defined line of the [Trotskyist] movement" towards the NDP, ${ }^{70}$ though the local found this command to be somewhat ambiguous and failing to offer the directional advice they had requested. As a result, the FYS decided to terminate all activity within the NDP until more specific instructions were issued. This move ensured that from early October on that the NB Waffle ceased to act as a unified entity, and a newer YS member left the organisation out of disgust 
with the FYS's behaviour. The non-Trotskyist wing of the NB Waffle was fed up with what they saw as the Trotskyists' slavish obedience to LSA dictates. The animosity between the two wings of the NB Waffle was exacerbated on 11 October when Dowson instructed the FYS to intervene in the NB NDP again, but to do so in the interest of preventing any further confrontation between the Waffle and non-Waffle sections of the party. ${ }^{71}$ Such an intervention would entail the FYS doing what it could to halt the NB Waffle's quest for victory.

The non-Trotskyist wing of the NB Waffle, well aware that the FYS had been commanded to seek peace between the group and the rest of the NB NDP, told the Trotskyist members to break ranks with the LSA or face reprisals. This threat was made clear at a York-Sunbury NDP riding association meeting on 15 October where the main item of business was the removal of Terry HamiltonSmith as the riding's representative on the provincial council. This move was made so that Hamilton-Smith could not intervene against the NB Waffle at the provincial council meeting scheduled for the following day. ${ }^{72}$ The anti-Waffle wing of the party had by this time agreed to suspend the continuation of the Saint John convention scheduled for 16 October until the federal NDP could mediate the dispute. In its place a provincial council meeting would be held on 16 October. The Waffle disagreed with this change and insisted that the convention would continue on 16 October. Pat Callaghan during this time also expressed an intention to run for NB NDP leader at the meeting. ${ }^{73}$ The multiple meetings of 16 October in Fredericton officially split the NB NDP in two, with both J. Albert Richardson and Pat Callaghan claiming to be party leader and possessing rival party executives. ${ }^{74}$ The non-Waffle wing of the party requested that the federal NDP deal with the split at the upcoming meeting of the federal council, scheduled for 12-14 November. The federal NDP agreed to do so. ${ }^{75}$

The NB Waffle was completely split after the events of 16 October. The Trotskyists were effectively cut out of the group and the FYS became increasingly frustrated with the leadership of the LSA. The local regarded its suspension as having engendered "the single largest setback in our work," having nullified the progress made by the Trotskyist movement in New Brunswick during the previous year and a half. The FYS was not silent in their denunciation of the LSA leadership's application of a doctrinaire policy towards the NDP that they believed was disastrous. As Terry Hamilton-Smith commented in a letter to the Political Committee of the LSA:

The only effect of the application of this line [towards the NDP] have been to pluck us out of the leadership of the Waffle, to undercut our work in the Waffle, to diminish our influence in the N.B. labour and student movements and to alienate a number of contacts from us who are potential recruits to the LSA/LSO or YS/LJS. With our diminished influence we can predict that the application of this line will have a totally insignificant effect on the present struggle in the NDP 
except to render our own role ineffective. As long as this particular line remains in force we will be crippled in New Brunswick. ${ }^{76}$

The position of the FYS towards the LSA leadership was clear: that they allowed doctrine regarding the NDP and fear of expulsion from the party to drive them towards voluntarily killing a major gain for Trotskyist influence over a provincial section of the NDP. Was not securing significant influence over the NDP supposed to be the whole point of entryism? In 1971, New Brunswick Trotskyists were about to "win the NDP to socialism," and yet saw this potential victory aborted by Trotskyists in Ontario, whom the FYS believed did not understand the situation in New Brunswick and were enforcing an entryist strategy designed for Toronto upon Fredericton. ${ }^{7}$

The NB Waffle's troubles were exacerbated at the NDP's federal council meeting on 12 November. The federal council passed a motion that suspended the NB NDP until it could be proven by federal party officers that the NB NDP had conducted a proper convention. A special convention date was set for 27 November in Chatham, at which time the dispute within the NB NDP would be finally resolved. ${ }^{78}$ The non-Trotskyist wing of the NB Waffle was naturally outraged by the federal council decision, and concluded that the group's future within the NB NDP was limited, as the non-Waffle forces would easily ensure that they had enough votes to defeat the NB Waffle at the Chatham convention. Some Wafflers entertained the notion of forming a separate party while Callaghan himself talked publicly of reviving the CCF in New Brunswick. The future of the NB Waffle would be decided at a meeting in Fredericton on 21 November. $^{79}$

The FYS tried unsuccessfully on the eve of the 21 November meeting to convince the NB Waffle to recognize the authority of the NDP federal council, to remain within the NB NDP "at all costs," and to attend the special convention in Chatham. The non-Trotskyist reaction to the suspension of the party was an active "Trot-baiting" campaign. Norman Strax, who joined the NB Waffle in the recruitment rush following the Saint John convention, circulated a letter attacking the FYS members as "sectarian Trotskyites" and recommended their exclusion from the NB Waffle. The FYS, sensing that they had no hope of winning over the whole of the NB Waffle, sought to engineer a split of the group at the 21 November meeting. The pro-Trotskyist minority would reconstitute themselves as a new NB Waffle, adopt the Ontario Waffle manifesto with a modified labour resolution, and attend the special convention yet not challenge the leadership, all in the interest of remaining within the NDP. ${ }^{80}$ By this point, the FYS was dedicated, grudgingly, to the LSA leadership's sole aim of preventing an expulsion of Trotskyists from the NDP.

The 1960s offered a plethora of incidents that suggested that the LSA leadership's fear of expulsions from the NDP were not misplaced. In 1962, eleven LSA members and supporters were expelled or suspended from the British 
Columbia NDP's Youth Section for being associated with the LSA. The expulsion of up to fourteen members of the Ontario NDP occurred in 1963 for the same reason ${ }^{81}$ and that same year also saw thirty Trotskyists belonging to the NDP's youth wing expelled. This purge of Trotskyists from the New Democratic Youth was repeated in 1967 with the expulsion of NDP youth members who were either LSA members or supporters. The impact of these expulsions was to temporarily negate any Trotskyist influence in the NDP's youth wing. ${ }^{82}$ These events were fresh in the memories of the LSA leadership in 1971 and certainly shaped their thinking about events in New Brunswick.

At the NB Waffle meeting on 21 November the demoralization of both the Trotskyist and non-Trotskyist wings of the group was noticeable. Just over 30 Wafflers attended, less than half the number who attended the 16 October meeting. Following a debate on the NB Waffle's future, a vote was held on a motion calling for the group to recognize the authority of the federal council and attend the special convention in Chatham. The motion passed by a vote of seventeen to fourteen. ${ }^{83}$ The FYS had gained control over the direction of the NB Waffle, albeit in its truncated form. The prominent non-Trotskyist members of the group accepted the vote and withdrew from any involvement in the NB Waffle.

Among the delegates at the special convention in Chatham were seventeen Wafflers, including six YS members. None of the prominent non-Trotskyist members attended, including Pat Callaghan. The primary aim of the YS members in attendance was to prevent their expulsion from the NB NDP. When it became apparent that one anti-Waffle NDP member, Ray LeBreton, was planning to introduce a motion that sought the expulsion of Waffle members, YS members cut a deal with LeBreton whereby he would scrap his motion in exchange for NB Waffle support for his provincial council candidacy. The convention saw non-Wafflers retake the NB NDP, with the acclamation of J. Albert Richardson as party leader. Only two Wafflers, neither of which were YS members, were elected to the provincial council. Following the provincial council elections, an executive meeting of the NB NDP was held in which it was decided that the leading NB Waffle members ought to be expelled. Seven Wafflers, none of whom were YS members, would be slowly expelled through allowing their party memberships to expire and refusing to renew them. ${ }^{84}$ With the end of the special convention, the conflict within the NB NDP came to an end. The NB Waffle also effectively came to an end.

The FYS had some bold plans for the NB Waffle following the special convention, but they were never put into practice. ${ }^{85}$ Firstly, the FYS still had to patch things up with the LSA leadership. While the suspension of the local was lifted on 22 October, it was replaced by the censure of several of its members for acts of "gross disloyalty." Secondly, the battle with Ross Dowson and the LSA leadership terminally weakened the YS in New Brunswick, making any future growth of the Trotskyist movement or the NB Waffle unlikely. By the end of 
1971 only the Fredericton YS local remained active in the province, with no more than nine members. ${ }^{87}$ All mentions of the NB Waffle at FYS meetings ceased by mid-December and the local became preoccupied with appealing their censure and activity at Fredericton High School. ${ }^{88}$ The FYS, and with it the Trotskyist movement in New Brunswick, completely fell apart during 1972. Membership declined, regular meetings ended in June, and Terry Hamilton-Smith both quit the LSA in July and left Fredericton along with other local Trotskyists. ${ }^{89}$ By the fall, the few remaining members were too demoralized to even pick up the local's mail and the FYS was dead by the end of the year. ${ }^{90}$

By the time of the FYS's demise, many LSA and YS members began to openly question and criticize the manner in which Ross Dowson and other LSA leaders handled the NB Waffle episode in late 1971. Trotskyists across Canada wondered if the LSA's pursuit of its dogmatic line towards the NDP had in fact been responsible for having aborted a potential major victory for the movement in New Brunswick. The first major salvo fired against Dowson and the LSA leadership came in November 1972 in the form of an article by Walter Davis, a member of the Toronto West YS. He accused the LSA Political Committee of practising a failed policy towards the NDP that "led to a debacle that has set back the left in [New Brunswick] for years to come." ${ }^{\text {"91 }}$ Additional comments made by Davis deserve to be quoted in length, for they illustrate the emerging critique of the particular application of entryism preached and practiced by the LSA:

Valuable revolutionaries were lost because the LSA/LSO leadership substituted organizational maneuvers for Marxist analysis. Trotskyism was smeared in Fredericton not by the YS comrade but by Labor Challenge ... the New Brunswick left which the YS had come close to having political hegemony over crumbled as a result of the Labor Challenge and P. Kent's tailism. Many fine militants were lost to politics thanks to this capitulation to the right-wing leadership of social democracy in Canada. ${ }^{92}$

What Davis specifically attacked in this statement was an article written by P. Kent in the LSA organ Labor Challenge in early October 1971 that Dowson instructed the FYS to follow. It emphasized that the local ought to intervene in the NB NDP solely to avoid any further confrontation between the Waffle and non-Waffle wings of the party. ${ }^{93}$ Davis concluded his tirade as such:

The tailism of the leadership caused the LSA to miss important opportunities for adding to the forces of Trotskyism in Canada. How many times will this be the case? The 1971 repression of the New Brunswick Waffle was led by the united forces of Lewis-Watkins-Dowson. The first two stand historically convicted of crimes against the revolution. The last must answer to the future. ${ }^{94}$

Davis was joined by another member of the Toronto West YS local, Bret 
Smiley, for another assault on the LSA's entryist policy in February 1973. The two co-wrote a polemic that argued that the LSA's entryist line towards the NDP rendered the Canadian Trotskyist movement vulnerable to absorption by reformist social democrats and therefore the policy of entryism was "criminal."

Don Van Wart, a former FYS member, joined in on the critiques being levied against the LSA leadership's entryist policy. In a paper entitled "The Double Demagogy of 'Winning the NDP to Socialism," written in January 1973, he asserted that the LSA leadership's actions not only killed the Trotskyist movement in New Brunswick, but that the LSA was ultimately not interested in "winning the NDP to socialism." As Van Wart elaborated:

The line of the LSA/LSO is 'Win the NDP to Socialism.' This is fairly clear in its content but it is also true that [the] leading cadre will confidently take you aside to explain that we don't in fact believe it at all, that this is a slogan for other people which we know is totally impossible. And so the meaning becomes somewhat ambiguous. ... the LSA/LSO policy is one of political liquidation into the NDP in exchange for minor areas of organizational control (e.g. Left Caucus) and security (i.e. not being expelled). The actual content of 'Win the NDP to Socialism' is the loss of the LSA to social democracy. ${ }^{96}$

Van Wart's accusation against the LSA leadership was severe, suggesting that the whole entryist project was nothing more than a sham, and that the LSA leadership was not interested in revolutionary action so much as interested in seeking shelter within the NDP. Revelations such as this gained currency in early 1973 as the Trotskyist movement suffered further setbacks elsewhere in Canada in their interventions within the NDP in general and the Waffle in particular. ${ }^{97}$

Ross Dowson and other LSA leaders believed that inclusion within the NDP trumped all other concerns, even if it meant aborting potential victories that could result in expulsion. The minor influence that could be secured via involvement in the NDP, it was asserted, accomplished more than operating in a small Trotskyist sect, and thus inclusion in the party had to be maintained at all costs. This argument had little sympathy among those Trotskyists to whom the very concept of entryism fell into disrepute. They questioned the point of being in a movement that paid lip service to revolution yet feared offending social democratic forces. Better to be excluded from the mainstream of the Canadian left, they argued, and at least remain loyal to revolutionary principles.

In some ways this conflict was the product of a generational gap that had emerged in the Canadian Trotskyist movement by the early 1970s, where veterans of the movement such as Dowson had to contend with younger members who joined during the ferment of the previous decade. Indeed, most of the Trotskyists in New Brunswick were very young, most of them only of early university age. Their political roots were not in the discipline of the Fourth International but in the less dogmatic New Left. This emerging generation gap was very much 
exposed by the events in New Brunswick in 1970-71. The fact is that the LSA was being torn apart by a scenario it never had to confront before: an actual victory for entryism. The NB Waffle represented the first time in Canadian history that a Trotskyist influenced platform became CCF or NDP policy and where Trotskyists were on the verge of becoming a major component of the power elite of the party. A significant Trotskyist gain within the NDP, until 1971 the stuff of conjecture, theory and speculation, had suddenly become reality.

The unfamiliarity of the scenario facing the LSA in New Brunswick in late 1971 was complicated by the fact that the NB Waffle victory occurred in a social democratic party that was not an established political force within the working class or labour movement. LSA doctrine stipulated that entryism should only occur and be allowed to succeed in an established social democratic party rooted in the working class and labour movement. This was fine in Ontario or British Columbia, where the NDP met these conditions, but what did it mean for Trotskyists living in areas where the party lacked these qualities, namely Fredericton in 1970-71? Trotskyists had to take a leading role in building the NDP in Fredericton in 1970-71, as there was little sign that the local NDP would be built otherwise and certainly not by the working class or trade unionists if it was. Indeed, by effectively becoming part of the central organisation of much of the NB NDP without much effort, the province's Trotskyists were not so much employing traditional entryism, which would entail entering a strong, established party. Entryism, as practised by Trotskyists in Fredericton in 1970-71, was more akin to party building rather than party infiltration.

As the manner in which the Trotskyist gains in New Brunswick did not conform to entryist theory, the LSA leadership sought to abort these gains. This of course nurtured a split between those in the LSA who were more dogmatic and those who were more pragmatic. There is a final irony to this aspect of the Trotskyist predicament regarding the NB NDP. It is that the NB Waffle victory convinced many labour leaders in the province, a majority of whom until 1971 expressed only a half-hearted interest in the NB NDP, of the need to be more actively involved in the party lest it otherwise fall into the hands of radicals. ${ }^{98}$ Therefore, the Trotskyists of New Brunswick contributed in an indirect way of further entrenching the NB NDP in the labour movement, thereby partly rectifying the very weakness of the party that the LSA's entryist theorists had bemoaned.

As long as Canadian Trotskyists failed to come close to winning even partial control over a provincial wing of the NDP, these matters could be conveniently ignored. The Trotskyist experience in New Brunswick in 1970-71, however, brought to the surface all sorts of serious questions about not only the theory and application of entryism, but also the sincerity of slogans like "Win the NDP to Socialism" and the commitment of the LSA leadership to revolutionary principles. The fall-out from the LSA leadership's handling of the Trotskyist movement in New Brunswick following the NB Waffle victory contributed to a reassessment 
of the LSA's policy towards the NDP, and seriously undermined the credibility of Dowson and other senior LSA leaders among Trotskyists who welcomed the nearvictory in the province. The authority of veteran Trotskyists was severely weakened and LSA members became increasingly confident in challenging other previously held assumptions within the movement.

The debates around entryism that were assisted by the events in New Brunswick, along with other debates within the Canadian Trotskyist movement, ensured that by the spring of 1973 that the unity of the LSA was no longer tenable. ${ }^{99}$ Those who opposed the NDP entryist strategy advocated by Dowson and other LSA leaders formed themselves in the spring of 1973 into the Revolutionary Communist Tendency. This group condemned the LSA's NDP policy as opportunist and adapting to reformism, and therefore as an abandonment of MarxistLeninist principles. Dowson's policies were defeated at the LSA's 1973 convention and the organisation's split was complete. Dowson and his supporters reconstituted themselves as the Labour Party Tendency, renaming the group as Forward the following year. Forward largely morphed into a personality cult around Dowson and when the various Trotskyist sects in Canada reunited in 1977, Dowson was not involved. ${ }^{100}$

The Trotskyist experience in New Brunswick between 1969 and 1972 presented the Canadian Trotskyist movement with fodder for one of its most challenging and fractious debates. New Brunswick's young and enthusiastic Trotskyists excelled at the art of entryism within the NDP, and in doing so exposed the gap between the LSA's espousal and promotion of entryist theories and the actual practice of said theories. The exposure of this gap threw the theory of entryism into a crisis that the Canadian Trotskyist movement could not remedy without significant internal fighting and eventual fracture. Following the events in New Brunswick of 1969-72, Canadian Trotskyists could no longer form their opinions on entryism upon theory alone. They would have a concrete example of momentarily successful entryism, and the crises it could initiate, upon which to ponder.

\section{NOTES}

1 The Waffle movement was begun in Ontario in the spring of 1969 by a group of NDP members who believed that the party was failing to address some of the most pressing political issues of the day, namely the rise of Quebec nationalism and the New Left and the threat to Canadian sovereignty posed by extensive foreign ownership of the Canadian economy. The Ontario Waffle called for the NDP to advocate a program of controls on foreign ownership and investment combined with nationalization of certain economic sectors, and to become more aligned with the New Left and Quebec nationalism. See Robert Hackett, "Pie in the Sky: A History of the Ontario Waffle," Canadian Dimension 15, 1\&2 (October-November 1980): 1-72 and John Bullen, "The Ontario Waffle and the Struggle for an Independent Socialist Canada: Conflict within 
the NDP," Canadian Historical Review 64, 2 (1983): 188-215, for the most thorough treatments of the Ontario Waffle. The author wishes to thank the University of New Brunswick and the Social Sciences and Humanities Research Council for the generous financial assistance in the completion of the research for this article.

Robert J. Alexander, International Trotskyism, 1929-1985: A Documented Analysis of the Movement, Durham, North Carolina: Duke University Press, 1991, 348-9.

3 Peter Shipley, “Trotskyism: 'Entryism' and Permanent Revolution,” Conflict Studies 81 (March 1977): 9.

4 Alexander, 348-9. The "French Turn" entryism proposals eventually provoked a split within the French Trotskyist movement into two competing organisations.

5 John Tomlinson, Left-Right: The March of Political Extremism in Britain, (London: John Calder Publishers Ltd., 1981), 64.

6 As this definition of entryism was employed by Tomlinson in the introduction of a piece about far left entryism in Britain, namely of the Trotskyist variant, the author feels comfortable using this definition.

7 Shipley, 9.

8 Alexander, 144-6.

9 Alexander, 147.

10 Alexander, 148.

11 Ross Dowson, The Socialist Vanguard and the NDP (Toronto: Socialist League, 1976), 14$5,25$.

12 "Found League for Socialist Action," June 1961, LS A/LSO Internal Discussion Bulletin 1970 (2), July 1970, file 42, A1-1970 (\#2), Vol. 1, Ross Dowson fonds, Library Archives of Canada. Prior to the 1950s, Canadian Trotskyists were organized under the banner of the Socialist Workers League followed by the Revolutionary Workers Party. The movement split into a series of regional groups during the 1950s. (Dowson, The Socialist Vanguard and the NDP, 14-7). The LSA was formed in 1960 as a formal fusion of independent Trotskyist branches in Toronto and Vancouver in 1960. ("Building the Revolutionary Party in Canada," submitted by the Political Committee of the LSA/LSO, in LSA/LSO Internal Discussion Bulletin 1970, 7 August 1970, p. 9, file 47, A1-1970 (\#7), Vol. 1, Dowson fonds, LAC.) The LSA became the Canadian affiliate of the United Secretariat of the Fourth International, which was formed in 1963 out of a split in the global Trotskyist movement. (Shipley, 5, 16).

13 May Richards to the editors or "View point," 1 September 1963; Lyle Kristiansen to May Richards, 5 September 1963, "NB YND 1961-71" file, Vol. 472, CCF-NDP fonds, LAC. Richards wrote to the editors of "Viewpoint" expressing concern over the political program of the LSA. Kristiansen's response to May was that she had "good reason to be wary of there people."

14 Eric Hobsbawm, Age of Extremes: The Short Twentieth Century, 1914-1991 (London: Abacus, 1994), 445. Hobsbawm commented that the Marxism espoused by student radicals during the late 1960s and early 1970s was "a peculiar seminar-oriented Marxism ... for it came out of the classroom, not the experience of working lives."

15 Nick Cohen, What's Left?: How Liberals Lost Their Way (London: Fourth Estate, 2007), 87.

16 John Braddock, "The Strax Affair: University of New Brunswick," Student Power and the Canadian Campus, ed. Tim Reid and Julyan Reid (Toronto: Peter Martin Associates 
Limited, 1969), 118. CSDS member Dan Weston commented that the group adopted the word "struggle" in their name instead of "students" because they were determined to show that "there were more than students involved." (Dan Weston, interview with author, Fredericton, N.B., 24 May 2007). The Strax Affair began in September 1968 as a protest by Strax and CSDS members against the introduction of identification cards for UNB students. It escalated to include Strax's suspension as a professor and a 48-day occupation of his office by students. The suspension also prompted a Canadian Association of University Teachers motion of censure against UNB over Strax's treatment. The affair was not settled until early 1969. For contemporaneous accounts of the Strax Affair, see John Braddock, "The Strax Affair: University of New Brunswick," Student Power and the Canadian Campus, ed. Tim Reid and Julyan Reid (Toronto: Peter Martin Associates Limited, 1969), 115-25, and Richard Wilbur, "Go Away ... (The Strax Affair)," Canadian Dimension 6, 8 (April-May 1970): 9-10, 54. For a historical analysis of the Strax Affair, see Peter C. Kent, "The Local, National and International Contexts of UNB's Strax Affair," The Officers' Quarters 23, 2 (Autumn and Winter 2005-06): 24-34.

17 Dan Weston, interview with author, Fredericton, N.B., 24 May 2007.

18 Eustace Mendis to Joe Young, 4 January 1970, file 78-8, "YS/LJS FrederictonCorrespondence and Minutes, n.d., 1970," Container 78, Canadian Trotskyist Movement fonds, LAC.

19 "The Trotskyist Movement in Fredericton: Results and Prospects," presented by the Fredericton YS to the 8 September 1970 YS/LJS plenum, 2 September 1970, file 7810, “YS/LJS-Fredericton-Reports and Correspondence, n.d., 1970," Container 78, Canadian Trotskyist fonds, LAC.

20 "The Trotskyist Movement in Fredericton: Results and Prospects," presented by the Fredericton YS to the 8 September 1970 YS/LJS plenum, 2 September 1970, file 7810, “YS/LJS-Fredericton-Reports and Correspondence, n.d., 1970," Container 78, Canadian Trotskyist fonds, LAC.

21 "CSDS Splits," The Brunswickan, 13 March 1970.

22 Terry Hamilton-Smith, "Decision-Making in Wonderland," 7-13 December 1969, file 10, “e3-1969," Vol. 54, Dowson fonds, LAC.

23 "The Trotskyist Movement in Fredericton: Results and Prospects," presented by the Fredericton YS to the 8 September 1970 YS/LJS plenum, 2 September 1970, file 7810, “YS/LJS-Fredericton-Reports and Correspondence, n.d., 1970," Container 78, Canadian Trotskyist fonds, LAC.

24 Eustace Mendis to Joe Young, 4 January 1970, file 78-8, "YS/LJS FrederictonCorrespondence and Minutes, n.d., 1970," Container 78, Canadian Trotskyist fonds, LAC; Terry Hamilton-Smith to Harry Kopyto, 25 February 1970, file 78-8, "YS/LJS Fredericton-Correspondence and Minutes, n.d., 1970," Container 78, Canadian Trotskyist Movement fonds, LAC. Terry Hamilton-Smith and his wife Carol made a rapid transition to Trotskyism in late 1969. As he put it in a letter to LSA member Jacquie Henderson in April 1970, "Our own development has been so rapid (six months ago we were innocent New Left!). (Terry Hamilton-Smith to Jacquie Henderson, 9 April 1970, file 78-8, "YS/LJS Fredericton-Correspondence and Minutes, n.d., 1970," Container 78, Canadian Trotskyist fonds, LAC).

"The Trotskyist Movement in Fredericton: Results and Prospects," presented by the 
Fredericton YS to the 8 September 1970 YS/LJS plenum, 2 September 1970, file 7810, "YS/LJS-Fredericton-Reports and Correspondence, n.d., 1970," Container 78, Canadian Trotskyist fonds, LAC. By May 1970, only two NBS members were not also FYS members: Bill Ross and Maxine Ross, both of whom would become key figures in the local NDP. (Carol Hamilton-Smith to Harry Kopyto, 4 May 1970, file 16, "E31970," Vol. 54, Dowson fonds, LAC).

26 "The Trotskyist Movement in Fredericton: Results and Prospects," presented by the Fredericton YS to the 8 September 1970 YS/LJS plenum, 2 September 1970, file 7810, "YS/LJS-Fredericton-Reports and Correspondence, n.d., 1970," Container 78, Canadian Trotskyist fonds, LAC.

27 Eustace Mendis to Ross Dowson, 11 May 1970, file 13-19, "Fredericton BranchMinutes and Correspondence, n.d., 1970-1972," Container 13, Canadian Trotskyist fonds, LAC. Pat Callaghan was also the federal NDP candidate in York-Sunbury in the 1965 and 1968 federal elections.

28 Bill Ross and Maxine Ross, interview with author, Fredericton, N.B., 14 December 2006.

29 Carol Hamilton-Smith to Harry Kopyto, 4 May 1970, file 16, "E3-1970,” Vol. 54, Dowson fonds, LAC.

30 Carol Hamilton-Smith to Harry Kopyto, 4 May 1970, file 16, "E3-1970," Vol. 54, Dowson fonds, LAC; Carol Hamilton-Smith to Harry Kopyto, 9 May 1970, file 16, "E3-1970," Vol. 54, Dowson fonds, LAC; Eustace Mendis to Ross Dowson, 11 May 1970, file 13-19, "Fredericton Branch-Minutes and Correspondence, n.d., 1970-1972," Container 13, Canadian Trotskyist fonds, LAC.

31 "The Trotskyist Movement in Fredericton: Results and Prospects," presented by the Fredericton YS to the 8 September 1970 YS/LJS plenum, 2 September 1970, file 7810, “YS/LJS-Fredericton-Reports and Correspondence, n.d., 1970," Container 78, Canadian Trotskyist fonds, LAC.

32 Report for the Political Committee by Dick Fidler and Anne MacDonald, 23 June 1971, file 3, "E3-1971," Vol. 55, Dowson fonds, LAC. Fidler and MacDonald suggested that LSA policies towards the Waffle should be to "encourage the Waffle to take initiatives within the framework of the NDP, to push the party into action in support of the left's anticapitalist demands."

33 Terry Hamilton-Smith to Anne MacDonald, 19 January 1971, file 13-19. "Fredericton Branch-Minutes and Correspondence, n.d., 1970-1972," Container 13, Canadian Trotskyist fonds, LAC.

34 "The Trotskyist Movement in Fredericton: Results and Prospects," presented by the Fredericton YS to the 8 September 1970 YS/LJS plenum, 2 September 1970, file 7810, "YS/LJS-Fredericton-Reports and Correspondence, n.d., 1970," Container 78, Canadian Trotskyist fonds, LAC. Terry Hamilton-Smith is referred to as the leader of the FYS in the agenda of the Atlantic Regional Socialist Conference, held in Halifax in March 1971. (Atlantic Regional Socialist Conference agenda, 13-14 March 1971, file 6/2, York-Sunbury NDP Association collection, MC1089, Provincial Archives of New Brunswick).

35 "The Trotskyist Movement in Fredericton: Results and Prospects," presented by the Fredericton YS to the 8 September 1970 YS/LJS plenum, 2 September 1970, file 7810, “YS/LJS-Fredericton-Reports and Correspondence, n.d., 1970," Container 78, 
Canadian Trotskyist fonds, LAC; R-J Gaudet, "Report on the Composition of the Fredericton Committee Against the War in Indo-China, 2 July 1970," file 78-10, "YS/LJS-Fredericton-Reports and Correspondence, n.d., 1970," Container 78, Canadian Trotskyist fonds, LAC; Carol Hamilton-Smith to Harry Kopyto, 9 May 1970, file 16, “E3-1970,” Vol. 54, Dowson fonds, LAC. In July 1970, FYS members made up 30 percent of the membership of Fredericton's Committee Against the War in Indo-China. The FYS also tried to organize a women's liberation group out of more militant members of the local chapter of Voice of Women in 1970.

36 Alexander, 147-50.

37 Alexander, 146.

38 Terry Hamilton-Smith to the Political Committee of the LSA/LSO, 25 October 1971, file 13-19, "Fredericton Branch-Minutes and Correspondence, n.d., 1970-1972," Container 13, Canadian Trotskyist fonds, LAC.

39 Terry Hamilton-Smith to Regina Modlich, 23 September 1970, file 13-19, "Fredericton Branch-Minutes and Correspondence, n.d., 1970-1972," Container 13, Canadian Trotskyist fonds, LAC.

40 Terry Hamilton-Smith to Ross Dowson, 9 August 1970, file 13-19, "Fredericton Branch-Minutes and Correspondence, n.d., 1970-1972," Container 13, Canadian Trotskyist fonds, LAC.

41 Fredericton Young Socialists NDP Fraction Report, 13 August 1970, file 78-10, "YS/LJS-Fredericton-Reports and Correspondence, n.d., 1970," Container 78, Canadian Trotskyist fonds, LAC; "Two-Party Race Likely For N.B.," The TelegraphJournal, 28 March 1963; "NDP Won't Enter Provincial Election," The Telegraph-Journal, 11 September 1967; "North Shore NDP Fields 3 Candidates," The Telegraph-Journal, 15 September 1967; "Party Endorses Candidates," The Telegraph-Journal, 3 October 1967; "Keep Your Own Election Score Monday Night," The Daily Gleaner, 24 October 1970.

42 Terry Hamilton-Smith to Regina Modlich, 23 September 1970, file 13-19, "Fredericton Branch-Minutes and Correspondence, n.d., 1970-1972," Container 13, Canadian Trotskyist fonds, LAC.

43 Memo from Maxine Ross to John F. Kinsel, 20 February 1971, private collection of Bill Ross. Total NDP membership in New Brunswick was 292 in February 1971, meaning that York-Sunbury and Carleton-Charlotte had 48.2 percent of the province's NDP members.

44 "Contact socialists in your area," Labor Challenge, 12 April 1971. The Sackville YS is listed in issues of Labor Challenge, the LSA paper, dating from 15 February 1971 until 26 April 1971.

45 Terry Hamilton-Smith to Regina Modlich, 23 September 1970, file 13-19, "Fredericton Branch-Minutes and Correspondence, n.d., 1970-1972," Container 13, Canadian Trotskyist fonds, LAC; Letter from Gary Zatzman to Maxine Ross, 5 April 1971, Bill Ross private collection; "Atlantic Organizer," 13 April 1971, file 74-24, "YS/LJS Local-Fredericton-Miscellaneous, n.d., 1970-1971," Container 74, Canadian Trotskyist fonds, LAC.

46 Letters from Terry Hamilton-Smith to Joe Young, 5 February 1971 and 21 February 1971, file 74-24, "YS/LJS LocalFredericton-Miscellaneous, n.d., 1970-1971," Container 74, Canadian Trotskyist fonds, LAC.

47 Terry Hamilton-Smith to Richard Ramsey, 1 March 1971, file 6/2, York-Sunbury NDP 
Collection, PANB. The Halifax YS, established in 1970, had nine members by February 1971. Total YS membership in the Maritimes in February 1971 was twentynine, up from two a year earlier. (Terry Hamilton-Smith to John Riddell, 21 February 1971, file 74-24, "YS/LJS LocalFredericton-Miscellaneous, n.d., 1970-1971," Container 74, Canadian Trotskyist fonds, LAC).

"Narcotics Control Act Amendments Urged By NDP," The Telegraph-Journal, 15 March 1971; "NDP Leader Says Party Split," The Telegraph-Journal, 24 March 1971; "Differences In NDP Patched Up," The Telegraph-Journal, 27 March 1971.

"Atlantic Organizer," 13 April 1971, file 74-24, "YS/LJS LocalFrederictonMiscellaneous, n.d., 1970-1971," Container 74, Canadian Trotskyist fonds, LAC.

50 "FYS NDP Fraction Report," 5 May 1971, file 74-24, "YS/LJS Local-FrederictonMiscellaneous, n.d., 1970-1971," Container 74, Canadian Trotskyist fonds, LAC; "Fredericton NDP in mayoralty bid," Labor Challenge, 7 June 1971; "NDP gains in N.B. civic elections," Labor Challenge, 5 July 1971. The NDP also ran two candidates in Fredericton for city council and three candidates for school board seats, along with three candidates for the school board in Black's Harbour/Beaver Harbour.

51 "Report on Regional Work in Moncton," 23 July 1971, file 74-24, "YS/LJS LocalFredericton-Miscellaneous, n.d., 1970-1971," Container 74, Canadian Trotskyist fonds, LAC.

52 "Fredericton Young Socialists Organizers Report," 3 July 1971, file 74-24, "YS/LJS Local-Fredericton-Miscellaneous, n.d., 1970-1971," Container 74, Canadian Trotskyist fonds, LAC.

53 "Fredericton Young Socialists Organizers Report," 19 July 1971, file 74-24, "YS/LJS Local-Fredericton-Miscellaneous, n.d., 1970-1971," Container 74, Canadian Trotskyist fonds, LAC; Terry Hamilton-Smith to the Political Committee of the LSA/LSO, 25 October 1971, file 13-19, "Fredericton Branch-Minutes and Correspondence, n.d., 1970-1972," Container 13, Canadian Trotskyist fonds, LAC. Among the post-convention strategies discussed was to form a revolutionary caucus that would seek to split the party into social democratic and revolutionary factions, a policy that seems somewhat contrary to the purposes of entryism.

54 Ross Dowson to the Fredericton and Halifax YS locals, 11 July 1971, file 13-19, "Fredericton Branch-Minutes and Correspondence, n.d., 1970-1972," Container 13, Canadian Trotskyist fonds, LAC; Terry Hamilton-Smith to the Political Committee of the LSA/LSO, 25 October 1971, file 13-19, "Fredericton Branch-Minutes and Correspondence, n.d., 1970-1972," Container 13, Canadian Trotskyist fonds, LAC.

55 Elaboration on Education plank of Waffle Manifesto.....

56 "NDP Report," passed by the Fredericton YS executive, 28 September 1971, to be introduced to the Fredericton YS, 2 October 1971, file 13-19, "Fredericton BranchMinutes and Correspondence, n.d., 1970-1972," Container 13, Canadian Trotskyist fonds, LAC; "Waffle Resolutions," file 3/3, York-Sunbury NDP Collection, PANB. Terry Hamilton-Smith authored the resolution on labour while Ron Gaudet authored the resolution on women's rights. The initials "PSC" and "AHR" appear at the end of all the other NB Waffle resolutions while these initials are absent for the labour and women's rights resolutions. This implies that Pat Callaghan and Alastair Robertson, another prominent non-Trotskyist Waffler, wrote the remainder of the manifesto and platform. 
57 "Resolution on Trade Unions and Labour Organization," in "Waffle Resolutions," file 3/3, York-Sunbury NDP Collection, PANB.

58 "Resolution on Women's Rights," in "Waffle Resolutions," file 3/3, York-Sunbury NDP Collection, PANB.

59 "Report on the Suspension and Censure of Members of the Halifax and Fredericton Locals of the YS/LJS," prepared by the Central Executive Council of the YS/LJS, file 1, "B2-1971," Vol. 20, Dowson fonds, LAC. The Halifax YS was also suspended in the same manner that the Fredericton YS was on 1 September 1971. Among the other charges levied against the FYS was that the local was producing two sets of minutes, one being a false set drawn up for the CEC, that the FYS held a "min-conference" with the Halifax YS in July 1971 without informing the CEC, and that the local failed to pay its share of the costs associated with a YS conference in Waterloo, Ontario held over the summer of 1971.

60 Terry Hamilton-Smith to the Political Committee of the LSA/LSO, 25 October 1971, file 13-19, "Fredericton Branch-Minutes and Correspondence, n.d., 1970-1972," Container 13, Canadian Trotskyist fonds, LAC.

61 "NDP Report," passed by the Fredericton YS executive, 28 September 1971, to be introduced to the Fredericton YS, 2 October 1971, file 13-19, "Fredericton BranchMinutes and Correspondence, n.d., 1970-1972," Container 13, Canadian Trotskyist fonds, LAC.

62 Terry Hamilton-Smith to the Political Committee of the LSA/LSO, 25 October 1971, file 13-19, "Fredericton Branch-Minutes and Correspondence, n.d., 1970-1972," Container 13, Canadian Trotskyist fonds, LAC.

63 "NDP Report," passed by the Fredericton YS executive, 28 September 1971, to be introduced to the Fredericton YS, 2 October 1971, file 13-19, "Fredericton BranchMinutes and Correspondence, n.d., 1970-1972," Container 13, Canadian Trotskyist fonds, LAC; "Waffle Manifesto Wins One-Vote Majority," The Telegraph-Journal, 27 September 1971. The number of delegates in attendance was mentioned in a letter from John Boyle to Cliff Scotton, 29 September 1971, file 13, "NB: Provincial Convention, 1971," Vol. 455, CCF-NDP fonds, LAC.

64 Report from A.P. Gleave to David Lewis, 27 September 1971, file 22-19, "NDP New Brunswick 1971-1974,” Vol. 76, MG 32, C 23, David Lewis fonds, LAC.

65 See Patrick Webber, “For a Socialist New Brunswick': The New Brunswick Waffle, 1967-1972" (M.A. Thesis, University of New Brunswick, 2008), 103-34, for the full details on the activities of the NB Waffle and its opponents during the split within the NB NDP in late 1971.

66 Ross Dowson to the Fredericton YS, 3 October 1971, file 74-24, "YS/LJS LocalFredericton-Miscellaneous, n.d., 1970-1971," Container 74, Canadian Trotskyist fonds, LAC. Dowson was first made aware of the NB Waffle manifesto victory from an article in the Toronto Star about Ontario NDP leader Stephen Lewis's reaction to the news from New Brunswick. Ontario was in the midst of an election campaign at the time.

67 Terry Hamilton-Smith to Ross Dowson, 29 September 1971, file 13-19, "Fredericton Branch-Minutes and Correspondence, n.d., 1970-1972," Container 13, Canadian Trotskyist fonds, LAC.

68 Ross Dowson to the Fredericton YS, 3 October 1971, file 74-24, "YS/LJS LocalFredericton-Miscellaneous, n.d., 1970-1971," Container 74, Canadian Trotskyist fonds, 
LAC.

69 “Walkout breaks up N.B. NDP convention," Labor Challenge, 11 October 1971.

70 Ross Dowson to the Fredericton YS, 3 October 1971, file 74-24, "YS/LJS LocalFredericton-Miscellaneous, n.d., 1970-1971," Container 74, Canadian Trotskyist fonds, LAC.

71 Terry Hamilton-Smith to the Political Committee of the LSA/LSO, 25 October 1971, file 13-19, "Fredericton Branch-Minutes and Correspondence, n.d., 1970-1972," Container 13, Canadian Trotskyist fonds, LAC; "Walkout breaks up N.B. NDP convention," Labor Challenge, 11 October 1971.

72 Terry Hamilton-Smith to the Political Committee of the LSA/LSO, 25 October 1971, file 13-19, "Fredericton Branch-Minutes and Correspondence, n.d., 1970-1972," Container 13, Canadian Trotskyist fonds, LAC.

73 Webber, 113-4.

74 "NDP Now Has Two Leaders," The Telegraph-Journal, 18 October 1971.

75 "Re: New Brunswick New Democratic Party," file 13, "NB: Provincial Convention 1971,” Vol. 455, CCF-NDP fonds, LAC.

76 Terry Hamilton-Smith to the Political Committee of the LSA/LSO, 25 October 1971, file 13-19, "Fredericton Branch-Minutes and Correspondence, n.d., 1970-1972," Container 13, Canadian Trotskyist fonds, LAC.

77 Terry Hamilton-Smith to the Political Committee of the LSA/LSO, 25 October 1971, file 13-19, "Fredericton Branch-Minutes and Correspondence, n.d., 1970-1972," Container 13, Canadian Trotskyist fonds, LAC.

78 "New Democratic Party: Minutes of Federal Council Meeting, 12-14 November 1971Ottawa," book 9 (1 of 2), file 367-4, CCF-NDP fonds, LAC.

79 "Claims NDP Constitution 'Violated'," The Telegraph-Journal, 15 November 1971; "NDP Waffle Members To Form Own Party?," The Telegraph-Journal, 19 November 1971; “CCF To Be Revived In Province?,” The Daily Gleaner, 15 November 1971.

80 Terry Hamilton-Smith to Ross Dowson, 17 November 1971, file 13-19, "Fredericton Branch-Minutes and Correspondence, n.d., 1970-1972," Container 13, Canadian Trotskyist fonds, LAC.

81 Lyle S. Kristiansen to May Richards, 5 September 1963, file “NB YND 1961-71,” Vol. 472, CCF-NDP fonds, LAC. Kristiansen stated that "between eight and fourteen" members of the Ontario NDP were expelled in early 1963 for being LSA members or supporters.

82 Benjamin Isitt, "Tug-of-War: The Working Class and Political Change in British Columbia, 1948-1972" (Ph.D. diss., University of New Brunswick, 2007), 364, 381-2.

83 "NDP Waffle To Stay Within Provincial Body," The Daily Gleaner, 22 November 1971.

84 “NDP Report," Fredericton YS, 4 December 1971, file 74-24, "YS/LJS LocalFredericton-Miscellaneous, n.d., 1970-1971," Container 74, Canadian Trotskyist fonds, LAC. Of the six YS members who attended the convention, five were from the Fredericton YS local and one was from the Saint John YS local.

85 “NDP Report," Fredericton YS, 4 December 1971, file 74-24, "YS/LJS LocalFredericton-Miscellaneous, n.d., 1970-1971," Container 74, Canadian Trotskyist fonds, LAC. Among the plans the FYS had for the NB Waffle were to establish links with the Waffle elsewhere, build up the group's presence in Saint John and Moncton and forge links with the labour movement. 
86 "Report on the Suspension and Censure of Members of the Halifax and Fredericton locals of the YS/LJS," by the Central Executive Committee of the YS/LJS, file 1, "B21971," Vol. 20, Dowson fonds, LAC.

87 The final listing of the Black's Harbour/Beaver Harbour YS local was in the 8 November 1971 issue of Labor Challenge, while the final listing of the Saint John YS local was in the 20 December 1971 issue of Labor Challenge, implying that the locals ceased in November and December respectively. Minutes of FYS meetings held in December 1971 all listed between four and nine people in attendance (File 74-24, “YS/LJS Local-Fredericton-Miscellaneous, n.d., 1970-1971," Container 74, Canadian Trotskyist fonds, LAC).

88 Minutes of FYS local, 18 December 1971, file 74-24, "YS/LJS Local-FrederictonMiscellaneous, n.d., 1970-1971," Container 74, Canadian Trotskyist fonds, LAC.

89 Terry Hamilton-Smith to Ross Dowson, 3 July 1972, file 75-11, "FrederictonCorrespondence and Minutes, n.d. 1972," Container 75, Canadian Trotskyist fonds, LAC; Don Tapscott to the Fredericton YS, 10 June 1972, file 75-11, "FrederictonCorrespondence and Minutes, n.d. 1972," Container 75, Canadian Trotskyist fonds, LAC.

90 Ron Gaudet to "Comrade Trew," 7 November 1972, file 75-11, "FrederictonCorrespondence and Minutes, n.d. 1972," Container 75, Canadian Trotskyist fonds, LAC. There is no evidence of correspondence between the FYS and LSA headquarters after November 1972, suggesting that the local faded out by the end of the month.

91 Walter Davis, "A Case Study of the LSA NDP Line in Practice: The New Brunswick Fiasco," 15 November 1972, LSA/LSO Discussion Bulletin 1972, 26 (January 1973), file 162-1, "Discussion Bulletins-Nos. 21-30, 1972-1973," Container 162, Canadian Trotskyist fonds, LAC.

92 Walter Davis, "A Case Study of the LSA NDP Line in Practice: The New Brunswick Fiasco," 15 November 1972, LSA/LSO Discussion Bulletin 1972, 26 (January 1973), file 162-1, "Discussion Bulletins-Nos. 21-30, 1972-1973," Container 162, Canadian Trotskyist fonds, LAC.

93 Terry Hamilton-Smith to the Political Committee of the LSA/LSO, 25 October 1971, file 13-19, "Fredericton Branch-Minutes and Correspondence, n.d., 1970-1972," Container 13, Canadian Trotskyist fonds, LAC; "Walkout breaks up N.B. NDP convention," Labor Challenge, 11 October 1971.

94 Walter Davis, "A Case Study of the LSA NDP Line in Practice: The New Brunswick Fiasco," 15 November 1972, LSA/LSO Discussion Bulletin 1972, 26 (January 1973), file 162-1, "Discussion Bulletins-Nos. 21-30, 1972-1973," Container 162, Canadian Trotskyist fonds, LAC.

95 Walter Davis and Bret Smiley, "Social Democracy and the LSA," LSA/LSO Discussion Bulletin, 29 (February 1973), file 162-1, "Discussion Bulletins-Nos. 21-30, 1972-1973," Container 162, Canadian Trotskyist fonds, LAC.

96 Don Van Wart, "The Double Demagogy of 'Winning the NDP to Socialism'," LSA/LSO Discussion Bulletin, 26 (January 1973), file 162-1, "Discussion Bulletins-Nos. 21-30, 1972-1973," Container 162, Canadian Trotskyist fonds, LAC.

97 Marv Gandall, "Our Liquidation into the Ontario Waffle: The Lessons to Learn from it," LSA/LSO Discussion Bulletin 1972-73, 44 (9 April 1973), file 162-3, "Discussion Bulletins-Nos. 41-58, 1973," Container 162, Canadian Trotskyist fonds, LAC. 
98 “NDP Report," Fredericton YS, 4 December 1971, file 74-24, "YS/LJS LocalFredericton-Miscellaneous, n.d., 1970-1971," Container 74, Canadian Trotskyist fonds, LAC. The newfound interest in the NB NDP among trade unionists in late 1971 was manifested in several ways. The Canadian Labour Congress (CLC) pressuring the New Brunswick Federation of Labour (NBFL) to participate more actively in the party. The CLC backed this up by sending a staff person to organize support for the NDP in the heavily-unionized Bathurst area. Trade unionists were more heavily represented on the NB NDP executive following the Chatham special convention, and there was a slight movement of NBFL officials into the party and an increase in the number of NDP-affiliated union locals in the province.

99 Alexander, 153-4. Both national and international forces precipitated the growing discord within the Canadian Trotskyist movement during 1973. The Fourth International was engaged in its own split between the European-dominated International Majority Tendency and the British Socialist Workers Party-led Leninist Trotskyist Faction, the latter of which attracted the bulk of Canadian Trotskyist support. Other issues of debate included the role of Anglo-Canadian nationalism vis-à-vis the United States as an anti-imperialist force and whether feminism was an "anti-Bolshevik" concern or not.

100 The Social History Project website (http://www.socialisthistory.ca) offers an excellent arrangement of sources cataloging the Canadian Trotskyist movement during the 1970s, especially after the fracturing of the LSA. See "Statement of the Political Committee," Old Mole, 5 (July-August 1973); Ian Angus, "Introduction," The 1973 Debate with Ernest Mandel; and Richard Fidler, "Ross Dowson, 1917-2002. 